\title{
Responses of Mmupudu (Mimusops zeyheri) indigenous fruit tree to three soil types
}

\author{
Phatu W. Mashela ${ }^{1 \star}$, Kgabo M. Pofu ${ }^{2}$ and Bombiti Nzanza ${ }^{1}$ \\ ${ }^{1}$ School of Agricultural and Environmental Sciences, University of Limpopo, Private Bag X1106, Sovenga 0727, \\ South Africa. \\ ${ }^{2}$ Agricultural Research Council, VOPI, Private Bag X293, Pretoria, 0001, South Africa.
}

Accepted 25 March, 2013

\begin{abstract}
Mmupudu (Mimusops zeyheri) is an indigenous fruit tree to South Africa, with the potential of being domesticated for its aesthetic and nutritional attributes in rural and urban communities which were historically settled on heavy clay and loam soils, respectively. A pot study was conducted to investigate the performance of $M$. zeyheri seedlings under loam, clay and sandy soils. Relative to loam, clay increased leaf growth by 19 to $20 \%$ and 9 to $58 \%$ at 9 and 12 months after transplanting, respectively, while sand consistently reduced leaf growth by 10 to $88 \%$ and 21 to $49 \%$, respectively. In conclusion, the positive performance of $M$. zeyheri on clay and loam soils enhanced its potential for domestication for rural and urban greening in South Africa.
\end{abstract}

Key words: Domestication, indigenous trees, moepel, vitamin C.

\section{INTRODUCTION}

Mmupudu (Mimusops zeyheri) fruit tree is indigenous to the northern parts of the Republic of South Africa and has high potential to serve in economic and nutritional projects in arid and semi-arid regions (Venter and Venter, 1996). Trees of M. zeyheri are evergreen and grow up to $15 \mathrm{~m}$ high, with non-aggressive lateral root systems and the tree species is both frost-hardy and drought-tolerant (Mashela and Mollel, 2001). Due to its high level of latex in above ground organs, the tree is relatively pest-free, except that ripe fruits are sensitive to an unidentified fruitborer. Additionally, the tree is resistant to the southern root-knot (Meloidogyne incognita) nematode, which is highly injurious to a wide range of crops (Pofu et al., 2012). The first leaf flush occurs in late winter (July to August), while the second, along with flowers, starts during late spring through early summer, when fruits are ready for harvest. Due to a large number of flowers and the high retention of both flowers and fruits, alternate fruit bearing is common in $M$. zeyheri trees. However, the intensity of alternate fruit bearing can be ameliorated through best management practices (Hartmann et al., 1988). Fruits are laterally borne, which implies that pruning is necessary for fruit production (Hartmann et al., 1988). Fruit of $M$. zeyheri have the highest vitamin $C$ per unit among locally available fruits, both endemic and exotic (Venter and Venter, 1996). The tree is particularly important in the amelioration of the incidence of scurvy, which is prevalent in these parts of the country.

In Limpopo Province, South Africa, M. zeyheri had been identified by local communities as an indigenous fruit tree with the potential for domestication in arid areas (Mashela and Mollel, 2001). Micropropagation and cultivation protocols for the tree are already advanced (Maila, 2001). Most marginal communities in Limpopo Province were historically settled in areas with soils of low agricultural potential, where clay and sandy soils

${ }^{\star}$ Corresponding author. E-mail: phatu.mashela@ul.ac.za. Tel: +27152682190. Fax: +272682892. 
are predominant (Mashela and Mollel, 2001). Incidentally, commercial farming and urban communities are situated in high potential agricultural soils such as loam. Soil type has a strong influence on the productivity of crops (Hartmann et al., 1988), which may be direct through physical abrasion of soil particles on the root system and/or indirect through the influence of the soil on the availability of water and/or nutrient elements (Hartmann et al., 1988; Mashela et al., 1991). The growth potential of $M$. zeyheri on different soil types is not documented. The objective of this study, therefore, was to determine the influence of three soil types (loam, clay and sandy soils) on the growth potential of $M$. zeyheri seedlings under greenhouse conditions.

\section{MATERIALS AND METHODS}

Loam soil was collected from the University of Limpopo Experimental Farm $\left(23^{\circ} 5310 \mathrm{~S}, 2^{\circ} 4415 \mathrm{E}\right)$, clay soil from Tzaneen $\left(23^{\circ} 5520 \mathrm{~S}, 30^{\circ} 0155 \mathrm{E}\right)$ and sand from Magatle Village $\left(24^{\circ} 2719 \mathrm{~S}\right.$, $\left.29^{\circ} 2339 \mathrm{E}\right)$. Soil samples collected from each soil type were sieved to pass through a 2-mm sieve, shade-dried and analyzed for soil particle distribution using the rapid method (Bouyoucos, 1961). Soil nutrients and $\mathrm{pH}$ for each soil texture were determined (Rhue and Kidder, 1983) and (1) loam soil comprised $31 \%$ sand, $59 \%$ clay and $10 \%$ slit, (2) clay soil $27 \%$, (3) sand, $70 \%$ clay and $3 \%$ silt, while sand constituents were $98 \%$ sand, $0.5 \%$ clay and $1.5 \%$ silt. Soil $\mathrm{pH}\left(\mathrm{H}_{2} \mathrm{O}\right)$ on clay, loam and sand were 7.52, 7.27 and 7.2, respectively. Quantities of nutrient elements in various soil types were negligible and therefore, supplemented using fertilizers which included macronutrients and micronutrients. Each of the three soil types was steam-pasteurized $\left(300^{\circ} \mathrm{C}, 1 \mathrm{~h}\right)$.

Seeds were planted in a 160-hole seedling tray potted with steam-pasteurized river sand. At 110 days after seeding, uniform seedlings were transplanted into $10 \mathrm{~L}$ plastic bags, each was filled to $9.5 \mathrm{~L}$ using separate soil types. Treatments, namely, clay, loam and sand, were arranged in a randomized complete block design, with 18 replications. Average day/night temperatures in winter (May to July) were $15 / 4^{\circ} \mathrm{C}$, spring (August to October) $18 / 10^{\circ} \mathrm{C}$, summer $25 / 17^{\circ} \mathrm{C}$ and autumn $20 / 11^{\circ} \mathrm{C}$. Maximum greenhouse temperatures were regulated using thermostatically-activated fans, while minimum temperatures depended upon the greenhouse effect. Seedlings were fertilized at transplanting using 2 g 2:1:2 (43), which provided a total of $0.35 \mathrm{mg} \mathrm{N}, 0.35 \mathrm{mg} \mathrm{K}$ and $0.16 \mathrm{mg} \mathrm{P}, 0.9 \mathrm{mg}$ $\mathrm{Mg}, 0.75 \mathrm{mg} \mathrm{Fe}, 0.075 \mathrm{mg} \mathrm{Cu}, 0.35 \mathrm{mg} \mathrm{Zn}, 1.0 \mathrm{mg} \mathrm{B}, 3.0 \mathrm{mg} \mathrm{Mn}$ and $0.07 \mathrm{mg}$ Mo per ml water and thereafter, bimonthly. Dolomitic lime at $5 \mathrm{~g} /$ pot to provide $\mathrm{Ca}$ and $\mathrm{Mg}$ was applied once during potting. Four sets of Hadeco Moisture Meters (Hadeco Magic ${ }^{R}$, New Delhi, India) were inserted to $20 \mathrm{~cm}$ depths in randomly selected pots of each treatment to monitor soil moisture tension. Plants were automatically irrigated with $500 \mathrm{ml}$ tapwater as soon as at least $50 \%$ of the moisture meters have average readings below 2 units with irrigation interval depending on soil type.

Data were collected at 9 and 12 months after transplanting. Four leaves/plant selected for measurements were tagged in order to ensure that data were collected from the same leaves. Chlorophyll meter (SPAD 502) was used to measure chlorophyll content from the tagged leaves. Stem root-collar diameters were measured at 3 $\mathrm{cm}$ above the soil surface using a digital vernier caliper. Plant height, leaf length, leaf width and leaf petiole length were measured. Plants were severed at the soil surface, with root systems removed from pots, immersed in water to remove soil particles, blotted dry and both roots and shoots dried at $70^{\circ} \mathrm{C}$ for $72 \mathrm{~h}$.

Data were analyzed using SAS software (SAS Institute Inc.,
2008). Data on number of leaves/plant were transformed using $\log _{10}(x+1)$ prior to analysis of variance to standardize the variances (Gomez and Gomez, 1984). Data were subjected to analysis of variance and means separated using Fisher's least significant difference test. Loam soil was used as a standard and data from clay and sand expressed relative to the standard using the relationship:

Impact $(\%)=[($ Mean performance on sand or clay soil/ Mean performance on loam soil -1$) \times 100]$.

\section{RESULTS AND DISCUSSION}

Soil type had no effect on chlorophyll content, dry shoot mass and dry root mass, while sand reduced root/shoot ratios of $M$. zeyheri seedlings (data not shown). Relative to loam soil, clay had no effect on plant height at 9 and 12 months. However, relative to loam soil, sand reduced this variable by 88 and $49 \%$ at 9 and 12 months, respectively (Table 1). Clay had no effect on stem diameter at 9 months, but increased the variable by $9 \%$ at 12 months. Sand significantly reduced the variable by 22 and $21 \%$ at 9 and 12 months, respectively.

Relative to loam, clay soil increased leaf width by $19 \%$ at 9 months and leaf petiole at 9 and 12 months by 20 and $19 \%$, respectively (Table 1 ). In contrast, sand consistently reduced various components of the leaf during both measurement periods. Dry shoot mass and root mass were not affected by soil type, which supported the view that $M$. zeyheri is a hardy plant (Venter and Venter, 1996). Using the two variables, it was previously demonstrated that $M$. zeyheri was resistant to the rootknot nematodes Meloidogyne species (Unpublished data), which are widespread in various parts of Limpopo Province (Kleynhans et al., 1996). Generally, M. zeyheri, like most indigenous plants in arid and semi-arid areas, is a slow grower, with dry shoot mass and root mass being poor indicators of growth (Maila, 2001). In this study, plant height, stem diameter and various components of the leaf were good indicators for assessing growth of $M$. zeyheri in response to soil type.

Relative to loam, clay soil had either no effect or increased the variables. Clay soil has high nutrient adsorption capabilities and high water holding capacities (Hartmann et al., 1988), all of which might have had an influence on the number of leaves and their growth potentials, which by 12 months had increased almost $50 \%$ more than at 9 months. Generally, most exotic fruit trees with either taproot or fibrous root systems, grow poorly on clay soil (Hartmann et al., 1988), probably due to their sensitivity to waterlogging conditions and soilborne diseases, which invariably induce root and crown rots (Agrios, 2005). Poorly developed taproot systems and hardy fibrous root system of $M$. zeyheri appear to be well-suited for clay soils, which are widespread in marginal rural communities of Limpopo Province.

Sand consistently reduced the indicators which were used for assessing growth potential of $M$. zeyheri, 


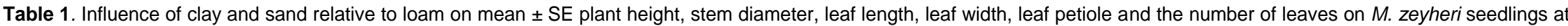
nine and twelve months after initiating the treatment $(n=54)$.

\begin{tabular}{|c|c|c|c|c|c|c|c|c|c|c|}
\hline \multirow{2}{*}{ Variable } & \multicolumn{5}{|c|}{9 months after initiating the treatment } & \multicolumn{5}{|c|}{ Twelve months after initiating the treatment } \\
\hline & Loam & Clay & Impact (\%) & Sand & Impact (\%) & Loam & Clay & Impact (\%) & Sand & Impact (\%) \\
\hline Plant height $(\mathrm{cm})$ & $6.8 \pm 1.8^{\mathrm{a}}$ & $7.0^{\mathrm{a}} \pm 1.2$ & $3^{\text {ns }}$ & $4.8 \pm 1.2^{b}$ & $-88^{*}$ & $13.0^{\mathrm{a}} \pm 2.1$ & $13.6 \pm 3.0^{\mathrm{a}}$ & $5^{\text {ns }}$ & $6.6 \pm 0.7^{b}$ & $-49^{*}$ \\
\hline Stem diameter (mm) & $2.4 \pm 0.5^{\mathrm{a}}$ & $2.6^{\mathrm{a}} \pm 0.6$ & $10^{\text {ns }}$ & $1.8 \pm 0.5^{\mathrm{b}}$ & $-22^{*}$ & $3.9^{\mathrm{b}} \pm 0.7$ & $4.3 \pm 1.7^{\mathrm{a}}$ & $9^{*}$ & $3.1 \pm 1.3^{c}$ & $-21^{*}$ \\
\hline Leaf length (cm) & $4.0 \pm 0.6^{\mathrm{a}}$ & $3.8^{\mathrm{a}} \pm 0.7$ & $-5^{\mathrm{ns}}$ & $4.1 \pm 0.4^{\mathrm{a}}$ & $2^{\text {ns }}$ & $6.2^{\mathrm{a}} \pm 1.39$ & $5.8 \pm 1.2^{\mathrm{a}}$ & $-6^{\text {ns }}$ & $4.1 \pm 1.1^{\mathrm{b}}$ & $-34^{*}$ \\
\hline Leaf width (cm) & $1.9 \pm 0.5^{b}$ & $2.2^{\mathrm{a}} \pm 0.6$ & $19^{*}$ & $1.4 \pm 0.1^{c}$ & $-44^{*}$ & $2.6^{a} \pm 0.8$ & $2.6 \pm 0.5^{a}$ & $2^{\text {ns }}$ & $1.9 \pm 0.6^{b}$ & $-28^{*}$ \\
\hline Leaf petiole (cm) & $3.4 \pm 0.9^{b}$ & $4.0^{a} \pm 2.0$ & $20^{*}$ & $3.1 \pm 1.4^{c}$ & $-10^{*}$ & $4.0^{b} \pm 0.8$ & $4.7 \pm 1.3^{\mathrm{a}}$ & $19^{*}$ & $3.0 \pm 1.0^{c}$ & $-23^{*}$ \\
\hline Number of leaves & $5.0 \pm 0.9^{\mathrm{a}}$ & $4.8^{a} \pm 0.5$ & $-5^{\mathrm{ns}}$ & $3.2 \pm 1.1^{\mathrm{b}}$ & $-36^{*}$ & $9.1^{b} \pm 2.1$ & $13.9 \pm 1.0^{\mathrm{a}}$ & $58^{*}$ & $6.37 \pm 1.3^{c}$ & $-30^{*}$ \\
\hline
\end{tabular}

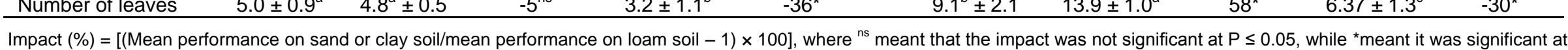

$P \leq 0.05$. Row means within a sampling period followed by the same letter were not different $(P \leq 0.05)$ according to Fisher's least significant difference test.

suggesting the high susceptibility of the indicators to soil type. Although there was no reduction in either dry shoot mass and dry roots mass, the integrated reduction of the number of leaves and components of the leaf due to soil type would eventually result in poor overall plant productivity, since the leaf is the major source of carbohydrates required for growth. Mashela et al. (1991) demonstrated that sandy soil consistently suppressed growth of Alyceclover (Alysicarpus vaginalis L.), a leguminous forage crop with a fibrous root system in Florida, USA. In that study, it was argued that roots were the most sensitive to sand damage and that the damage was mainly due to physical abrasiveness of sand particles, although other factors such as water stress and deficiency of nutrient elements were not ruled out. The observed reduction in stem diameter due to sand in M. zeyheri seedlings is consistent with the increased flow of sucrose to the root system whenever plants are subjected to extrinsic factors that reduce the root/shoot ratio (Mafeo, 2005). The increased flow of carbohydrates in the form of sucrose is intended to assist the plant to increase growth of the root system in order to re-establish the normal root/shoot ratio (Mashela and
Nthangeni, 2002).

\section{Conclusion}

Most rural communities in South Africa were historically settled in areas with heavy clay soils. Results of this study suggested that $M$. zeyher trees would be suitable for soil conditions with both clay and loam soils, while areas with sandy soils would be unfavourable. Since urban and certain rural areas have predominantly loam and clay soils, respectively, prospects for domesticating $M$. zeyheri trees are good in terms of its performance on the two soil types.

\section{ACKNOWLEDGEMENTS}

The authors are grateful to the Land Bank Chair, University of Limpopo for financial support.

\section{REFERENCES}

Agrios GN (2005). Plant pathology, 5th ed. Academic Press: London. p. 952.
Bouyoucos GJ (1961) Hydrometer method improved for making particle size analysis of soils: Agron. J. 54:464-465.

Gomez KA, Gomez AA (1984). Statistical procedure for agricultural research, 2nd ed. Wiley: New York. p. 680.

Hartmann HT, Kester DE, Davies AM, Geneve RL (1988). Plant propagation: Principles and practices, 8th ed. Prentice Hall: New York. p. 896

Kleynhans KPN, Van den Berg E, Swart A, Marais M, Buckley NH (1996). Plant nematodes in South Africa. Plant Protection Institute: Pretoria. p. 165

Mafeo TP (2005). Propagation, fertilization and irrigation of Cucumis myriocarpus. MSc Dissertation, University of Limpopo, Sovenga, South Africa.

Maila YM (2001). In-vitro propagation of Mmupudu (Mimusops zeyheri) fruit tree. Master Dissertation, University of the North, Sovenga, South Africa.

Mashela PW, Nthangeni ME (2002). Osmolyte allocation in response to Tylenchulus semipenetrans infection, stem girdling and root pruning in citrus. J. Nematol. 34:273-277.

Mashela PW, Mollel N (2001). Farmer - identified and selected indigenous fruit tree with suitable attributes for smallholder farming systems in South Africa's Northern Province. S. Afr. J. Ext. 30:1-12.

Mashela PW, McSorley R, Duncan LW (1991) Correlation of Belonolaimus longicaudatus, Hoplolaimus galeatus and soil texture with yield of Alyceclover. Nematropica 21:177-184.

Pofu K, Mashela P, De Waele D (2012). Survival, flowering and productivity of watermelon (Citrullus lanatus) cultivars in inter-generic grafting on nematode-resistant Cucumis seedling rootstocks in Meloidogyne-infested fields. Int. J. Agric. Biol. 14:217-222.

Rhue RD, Kidder G (1983). Procedures used by IFAS extension 
soil laboratory and interpretation of results. Circ. No. 595. FI. Co-op. Ext. Serv., IFAS, Univ. FI., Gainesville.

SAS Institute (2008). Statistical analysis systems computer package, Cary, New York, USA.

Venter F, Venter JA (1996). Making the most of indigenous trees. Briza Publications: Pretoria. p. 304. 